\title{
Study on the Problems of Management Shareholding and the Mixed Ownership
}

\author{
Gao Li, Song Shanshan
}

International Business School, Tianjin Foreign Studies University, Tianjin, China

Email address:

sophia_gaoli@aliyun.com (Gao Li),2077009026@qq.com (Song Shanshan)

\section{To cite this article:}

Gao Li, Song Shanshan. Study on the Problems of Management Shareholding and the Mixed Ownership. International Journal of Economics, Finance and Management Sciences. Vol. 5, No. 6, 2017, pp. 304-311. doi: 10.11648/j.ijefm.20170506.15

Received: August 19, 2017; Accepted: October 28, 2017; Published: November 20, 2017

\begin{abstract}
In recent years, managerial ownership has begun to be used as an incentive mechanism in China. Managerial ownership is one of the ways to realize the mixed ownership reform of state owned enterprises. In this paper, the impact of executive stock ownership on corporate performance of China's state-owned listed companies that mixed ownership has been achieved is analyzed. The conclusions are as follows: the state-owned listed companies management ownership and corporate performance has a positive correlation. The financial performance of the company increases with the proportion of management shareholding, ownership concentration and equity balance. There is a significant negative correlation between the proportion of independent directors and the rate of return on net assets, which shows that the independent directors of state-owned enterprises in China have not played its due role in the governance of state-owned enterprises.
\end{abstract}

Keywords: State-Owned Enterprises, Mixed Ownership, Managerial Ownership, Corporate Performance

\section{Introduction}

\subsection{Research Background and Significance}

\subsubsection{Research Background}

Since the reform and opening up, the state-owned enterprises as the center of economic structural reform in order to improve the operating efficiency of production enthusiasm and experienced management reform, ownership reform, reform of non-tradable shares and the stock after the age. [1]

Plan production orders strict control of severe repression of the production enthusiasm, so there are the production plan, tax, contract leasing policy, to a certain extent, to expand the business enterprise autonomy. But ownership did not let go, and go with the right to operate the business operators in the power range and the total disregard for the interests of owners, the blind pursuit of profit, lead to new problems, which is why the next step of reform of the ownership.

"Invigorating Large Enterprises and Relaxing Control over Small Ones" strategy did not reverse the loss of state-owned enterprises of the situation, so as to establish the goal of socialist market economy and state-owned enterprises changed to state-owned enterprises as a symbol of the ownership reform officially began 1990s. In 1993, the first company law of China defined property right relations explicitly, and pointed out that the establishment of corporate governance structure. To some extent, the relationship between owners and managers has been checked and checked, and the modern enterprise system has been gradually established. In the fourth Plenary Session of the 15th CPC Central Committee, the state-owned economy was strategically adjusted, which specifies which industries and areas need to be controlled by the state-owned economy.

In 2002, after the restructuring of township enterprises, the large-scale restructuring of state-owned enterprises broke out, at this time, the lack of standardized restructuring, frequent violations, so in 2003, the SASAC was established. The restructuring operation has been standardized, but because the Commission has just been established, the state-owned assets management system is not perfect, imperfect understanding of stock system and securities market, equity division problems, enterprise development funds, capital market liquidity is poor, the SASAC dominated stockholder structure reform.

The completion of the share reform, to a certain extent to solve the problems of corporate governance of listed 
companies, but the governance structure of state-owned enterprises is still not perfect, the lack of vitality of state-owned enterprises, from 1997 this mixed ownership economy includes national ownership and collective ownership economy, the theory has developed, but the advantages of mixed ownership is not fully reflected, the third Plenary Session of the 18th CPC Central Committee gives new connotation to promote mixed ownership mixed reform of state-owned enterprises, to change the mix of advantages, state-owned enterprises to achieve breakthrough development. As a socialist country, China's state-owned enterprises play a very important role in the national economy, while the reform process of state-owned enterprises and the effect of reform have a bearing on the overall situation of the national economy and the future of the nation. The reform of state-owned enterprises is not only through the private capital to join the property structure change, and management stock ownership has become a breakthrough point of reform. Based on this background, this paper empirically studies the impact of managerial ownership on corporate performance.

\subsubsection{Significance}

On the theoretical side, China's state-owned enterprises of mixed ownership reform will enter the breakthrough stage, as one of the important way to realize the mixed ownership, shareholding of management research is very important, although the managerial ownership has relatively rich literature, but because the state-owned enterprise of China has its own uniqueness, this paper based on the full consideration of China's state-owned enterprises and foreign-funded enterprises and private enterprises of different, use the method of empirical research to analysis the present stage of mixed relationship between managerial ownership and performance of the enterprise ownership reform, is to supplement the relevant research at home and abroad, and provide data support for the theoretical research have important significance in the reform of mixed ownership and managerial ownership theory.

In practical terms, as a socialist country, China's state-owned enterprises play a very important role in the national economy, while the reform process of state-owned enterprises and the effect of reform have a bearing on the overall situation of the national economy and the future of the nation. In order to achieve a breakthrough development of state-owned enterprises, state-owned enterprises to enhance vitality and competitiveness, mixed ownership reform came into being, based on the reading of related literature at home and abroad, with the latest data of the reform of state-owned enterprises, the empirical study of the relationship between managerial ownership and corporate performance, and tries to provide reference for the present stage of China's state-owned enterprises mixed the implementation and improvement of management stock ownership reform, mixed ownership reform to break the bottleneck of the development of state-owned enterprises to provide support, and effectively improve the operating performance of state-owned enterprises, state-owned enterprises to enhance the vitality and competitiveness in the market, mixed ownership reform and management ownership goals.

\subsection{Literature Review}

\subsubsection{Overseas Research Status}

There are foreign literature about ownership of the hybrid, W. Brus and K. Laski (1998) pointed out that if a country has a single state ownership will lead to lower productivity, inhibit the development of productivity, and increase the political bureaucracy and autocratic phenomenon. [22] And Stiglitz (1997) pointed out that state-owned enterprises are no less efficient than private enterprises. [8] In terms of managerial ownership, Sanders and WM. Gerard (2007) of the managerial ownership and corporate performance, considering the behavior of the executives, cash flow, corporate nature of three factors, that there is a positive correlation between corporate performance and managerial ownership conclusion. [9] Martin and Graham (2001) empirically study the relationship between managerial ownership and firm performance, and select 100 listed companies in the UK as samples. The results show that there is a positive correlation between them. [10] H. Youny and Joung (2003) based on the data from 1995-1998 as samples, empirical analysis of the relationship between executive equity incentive and corporate performance, found that when added to the cost of equity capital and equity value of cost factor, executive equity incentive not only improve the company performance, but the average performance has become a negative. [11] Mehran (1995) takes American industrial enterprises as a sample, and studies data from 1979 to 1980 , and points out that there is a significant positive correlation between CEO's shareholding and operating performance. [12] Merkel, Selev and Visny (1988) to select the 1980 "fortune" magazine ranked the top 371 companies in the 500 data as the sample, the value of Tobin Q as the company's performance index, find the director ownership and Tobin Q significant non monotonic relation, in the $0 \%$ to $5 \%$ range, and with the increase of Tobin $\mathrm{Q}$ the equity increased; in $5 \% \sim 25 \%$ range, Tobin's $Q$ value with increasing directors equity reduction; and when the equity of more than $25 \%$, they both showed positive correlation between. [13]

\subsubsection{Domestic Research Status}

Chinese scholars also deeply analyzed the mixed ownership, Ye Genying (2014) the development of mixed ownership economy financial thinking [16], Li Yueping (2015) return to the essence of an enterprise: all the paths of the reform of the state-owned enterprises of mixed [3] and Yang Jian Jun (2014) key large state-owned enterprises of mixed ownership reform is the scholars in China of mixed ownership theory. [2] For managerial ownership, Wei Gang (2000) empirically tested the relationship between executives and business performance, and concluded that the company's performance was positively related to the assumption of 
executive stock ownership. [17] Li Zengquan (2000) the empirical analysis concluded that, when the shareholding ratio is not high, no incentive to the manager, including the chairman and general manager, when the shareholding of managers to a certain extent, the level of ownership will have obvious effect. [4] Yuan Zhizhong and Zhu only chose 2006 and 2007 in Shanghai and Shenzhen A shares listed 29 Real Estate Company as a sample of corporate performance, empirical study found that there was a significant positive correlation of real estate listed company executives shareholding and corporate performance. [5]

\subsubsection{Commentary}

Through the above analysis of the research status at home and abroad, can be found on mix change theory, while the literature on the research on the managerial ownership and corporate performance is rich, but with the use of the method of regression of the dependent variables in the model variables are inconsistent, index performance is not the same, the conclusions present relevant and irrelevant interval related diversification. The innovation and the breakthrough lies in combining with the particularity of China's state-owned enterprises and the newest information about managerial ownership, and select the relevant and latest data. Through the combination of theoretical analysis and empirical test of the managerial ownership and corporate performance in order to discover the problems of the reform of state owned enterprises in China and put forward countermeasures and suggestions.

\section{The Particularity of State-Owned Enterprises and the Current Situation of Management Shareholding}

\subsection{Particularity of State Owned Enterprises}

The public ownership of the means of production is the economic foundation of China. The state-owned enterprise is an important form of public ownership. The basic premise of the reform of state-owned enterprises is to uphold the leadership of the party to the state-owned enterprises. Therefore, the leadership of state-owned enterprises is different from that of private enterprises, and the decision-making of state-owned enterprises is not only a decision-making of an enterprise, but also a market economy organization, not only seeking profits, but also carrying on the economic functions. [7]

\subsubsection{State-Owned Enterprises Are Political and Economic Unity}

The state-owned enterprises as the enterprise, is the market economy organization, responsible for economic function, while state-owned enterprises belong to the political organization -- all countries, for certain political function, so the state-owned enterprises will be unified in the political and economic development, in addition to market management, participate in market competition, make a profit, but also as a carrier of government macro-control. The most striking difference between state-owned enterprises and other enterprises lies in the fact that under the restriction of dual objectives of politics and economy, the profit maximization is not the highest goal, and the state-owned enterprises in western countries can hardly achieve their own profit and loss.

\subsubsection{State-Owned Enterprises Are the Tools for the Government to Implement Policies}

When the economic recession or inflation, the market out of balance, the need for macro-control, the state-owned enterprises to implement the government policy tools, functions will be reflected. Expanding or reducing investment in state-owned enterprises and raising or lowering prices of state-owned enterprises are common macro-control measures. As a state-owned enterprise, the function of policy tools is not only embodied in the country, but also applied to foreign affairs, so as to implement foreign policy or settle international disputes peacefully. In addition, it is not because China is a socialist country that state-owned enterprises are used as a tool for the government to implement policies. In the western market economy, state-owned enterprises are also required to make up for market deficiencies and stabilize economic development. [14]

\subsubsection{State-Owned Enterprises Have Dual Nature of Society and Enterprise}

In western economics, the private sector, family and government departments are the main body of the national economy, and the government departments are composed of state-owned enterprises and the general administrative departments relying on financial allocations. [15] The state-owned enterprises as the enterprise, has and other enterprise similarity, state-owned enterprises also earn income profit by providing products or services and other activities, the state-owned enterprises belong to the state, by direct state control and supervision, is the formal implementation of policy tools are similar and of government affairs.

State ownership is exclusive of state ownership. Public ownership is not unique to China, and state ownership also exists in Western countries. The nature of state ownership is naturally the same as in China and the west. But state-owned enterprises have different missions under different social systems. The mission of China's state-owned enterprises is mainly to ensure the prosperity, stability, security and development of the country, in order to improve the material and cultural standard of living of all the people, and to achieve common prosperity. The mission of state-owned enterprises in western countries is to ensure the maximization of the interests of the state and to provide material support for the development of the count.

\subsection{The Reform of Mixed Ownership and the Current Situation of Management Shareholding}

As of January 2015, China's 90\% state-owned enterprises 
completed the reform of the share structure, the assets attributable to listed companies reached $70 \%$. The assets of the mixed ownership listed companies exceed ninety percent of the assets of the listed central enterprises. The split share structure reform has solved the problem of saving the state-owned enterprises, and 2/3 of state-owned enterprises have realized the mixed ownership. However, due to various reasons, the state-owned enterprises still lack vitality and market competitiveness. From Figure 1 Figure 2 that SOE profit growth is not stable, and the 2012 profit growth rate is about $-6 \%$, the 2013 profit growth rate of $6 \%$, and insufficient to compensate for the losses before, while the 2013-2015 annual profit growth rate has dropped to below $-6 \%$, serious losses of state-owned enterprises, a small increase in 2016. From 2012 to 2015, the loss rate of state-owned enterprises was far higher than the loss rate of Enterprises above designated size.

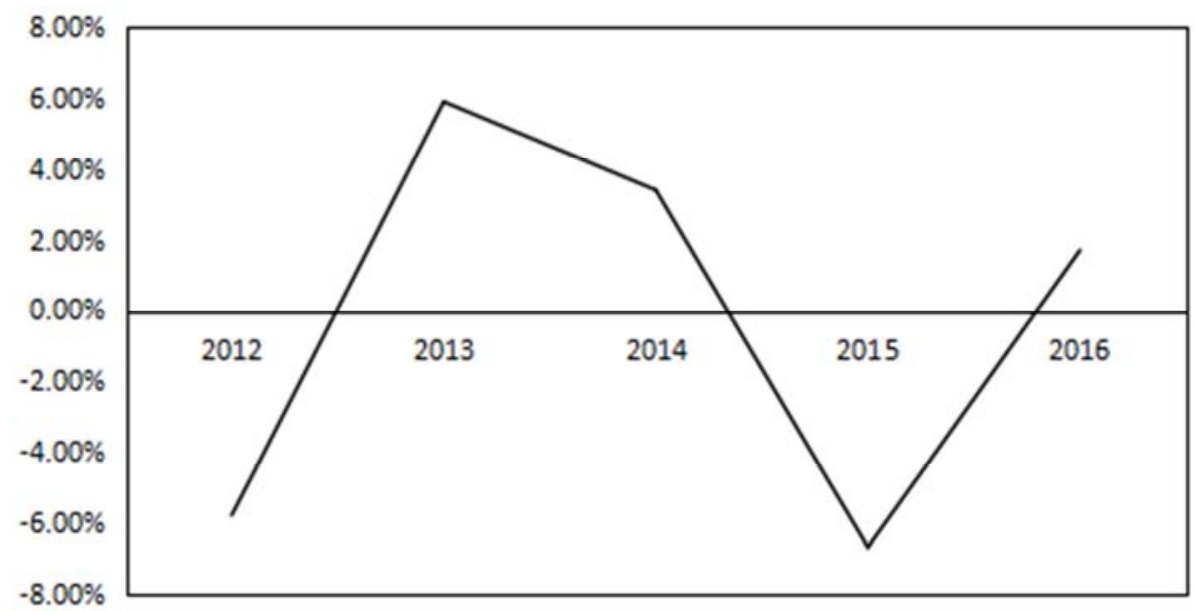

Figure 1. 2012-2016 profit growth rate of state-owned enterprises.

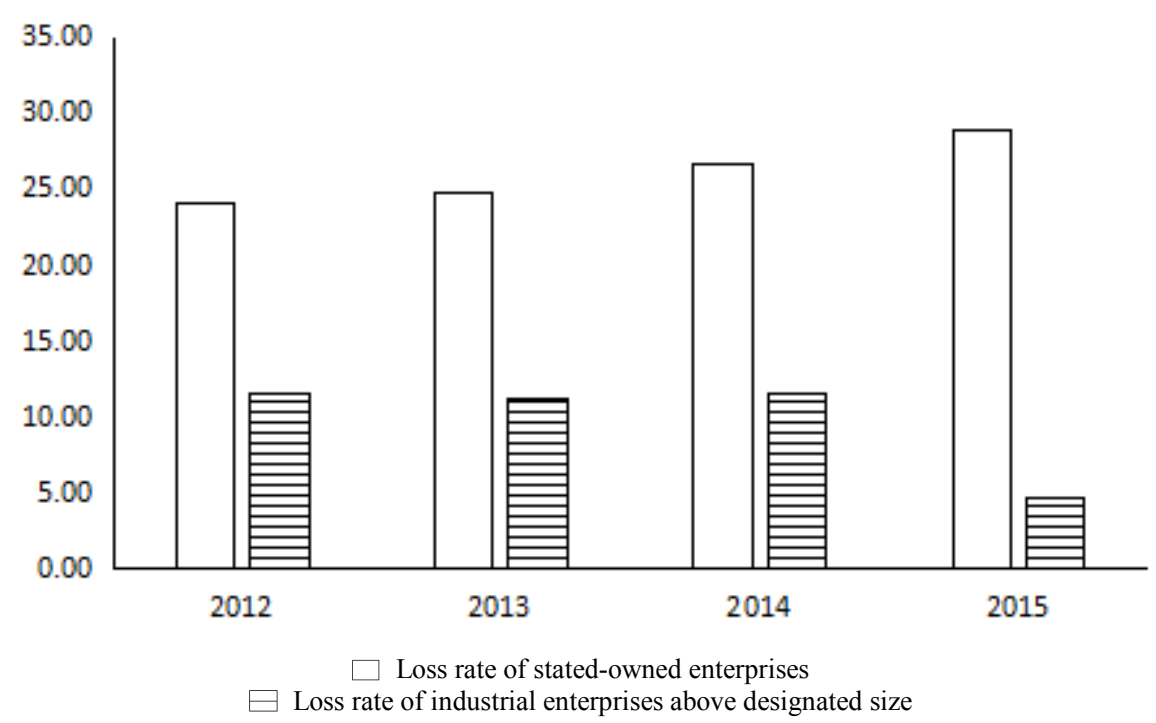

Figure 2. 2012-2015 loss rate of state-owned enterprises and Industrial Enterprises above Designated Size.

The concept of mixed ownership was put forward for the first time in ten years, and the mixed ownership reform did not play its proper role. Therefore, in the third Plenary Session of the 18th CPC Central Committee, the positive development of mixed ownership economy was put forward again. And clearly pointed out the new connotation and function of mixed ownership, mixed ownership economy from a macro point of view refers to the diversified ownership structure of a country or region, that is in the ownership structure includes not only the public sector of the economy also contains non father-in-law economic system. [18] This article, in line with the concept of mixed ownership proposed in the third Plenary Session of the 18th CPC Central Committee, refers to the mixed ownership of capital or mutual participation in different economic units of different ownership at the micro level.

\section{Research Design}

\subsection{Variable Selection}

Analysis of the particularity of China's state-owned enterprises above mentioned, the state-owned enterprise is the combination of social enterprises, both social and 
political goals, and the economic profit targets, from the business point of view, the net asset rate of return to measure the company's performance as the dependent variable, the famous DuPont model shows the overall net assets rate of return and typical, it can show the comprehensive sales, cost control, capital operation and financing structure, reflect the enterprise solvency and operation and profitability of [19], so the choice of the rate of return on net assets is a reasonable measure of corporate performance.

In the selection of variables, the proportion of managerial ownership is the management shareholding enterprise number divided by the total number of ordinary shares results.

Ownership concentration is the first largest shareholder number divided by the total number of ordinary shares in the company. Equity balance degree is the largest shareholder of the number of shares of the top ten shareholders holdings ratio. The controlling variables include the proportion of independent directors, the growth rate of assets, liabilities and operating income.

The overall variable definition is shown in table 1 :

Table 1. Variable definition table.

\begin{tabular}{|c|c|c|c|}
\hline Variables & categorical variables & names, symbols & variables, explanations, and formulas \\
\hline \multirow{4}{*}{$\begin{array}{l}\text { Dependent variable, } \\
\text { Independent variables }\end{array}$} & net asset yield & ROE & net profit / average total net assets \\
\hline & management share & MTO & management shares and common shares of the company \\
\hline & ownership concentration & $\mathrm{OC}$ & largest shareholder's number of shares held / total number of shares \\
\hline & Degree of equity restriction & SPR & $\begin{array}{l}\text { largest shareholder holding shares / second to tenth major } \\
\text { shareholders and the sum of shares }\end{array}$ \\
\hline \multirow[t]{3}{*}{ Control variables } & Debt ratio & DR & Total liabilities/total assets \\
\hline & Enterprises growth & EG & $\begin{array}{l}\text { revenue from the end of this year - revenue at the end of the year) / } \\
\text { last year's operating income }\end{array}$ \\
\hline & Proportion of independent directors & ID & number of independent directors / Directors \\
\hline
\end{tabular}

\subsection{Model Building}

The principal-agent theory suggests that the interests between company owners and managers are not consistent with, managerial ownership, which allows managers to hold shares, which has the right to operate and have certain ownership, management of both operating income and equity, balance their own interests, to solve the principal-agent problem. In domestic and foreign research literature, management stock ownership is also an important way to solve the principal-agent problem. This paper studies the relationship between managerial ownership and firm performance:

Hypothesis: there is a significant positive correlation between managerial ownership and corporate performance of state-owned listed companies.
Build the model as follows:

$$
\mathrm{ROE}=\alpha_{0}+\alpha_{1} \mathrm{MTO}+\alpha_{2} \mathrm{OC}+\alpha_{3} \mathrm{SPR}+\alpha_{4} \mathrm{DR}+\alpha_{5} \mathrm{EG}+\alpha_{6} \mathrm{ID}+\varepsilon
$$

\section{Empirical Study}

\subsection{Sample Selection and Descriptive Statistics}

The management of a clear stake in the Shanghai Stock Exchange listed A shares in the annual report of 205 state-owned listed companies in 2015 as the sample data, which removed the ST company, the main variable company excluding incomplete data, data from the annual reports of listed companies and the wind database, and then analyze the sample data by using Excel and SPSS software.

Table 2. Sample description.

\begin{tabular}{llllllll}
\hline & ROE & MTO & OC & SPR & DB & ID & EG \\
\hline N & 205 & 205 & 205 & 205 & 205 & 205 & 205 \\
Range & 94.68 & 80.98 & 73.46 & 2105.5 & 89.59 & 41.67 & 174.85 \\
Min & -63.77 & 0 & 5.43 & 19.35 & 4.08 & 25 & -68.15 \\
Max & 30.91 & 80.98 & 78.89 & 2124.85 & 93.67 & 66.67 & 106.71 \\
Mean & 7.89 & 14.23 & 33.51 & 240.79 & 49.00 & 36.74 & 5.81 \\
Std. D & 11.72 & 21.05 & 14.99 & 304.76 & 20.58 & 6.06 & 23.93 \\
\hline
\end{tabular}

As can be seen from table 2, the maximum and minimum asset yield of 205 state-owned enterprises are $30.91 \%$ and $-63.77 \%$, with an average value of $7.8866 \%$, and the state-owned enterprises' net asset yield is very different. The minimum value of management shareholding ratio is 0 , and the selection of sample selection in the annual report has shown that the management of a clear ownership of the enterprise, the 0 may by the data of four to five homes in which it can be seen that some state-owned enterprises, management shareholding ratio is very low. The maximum degree of ownership balance reaches 2124.85, which shows the power of the largest shareholder. The minimum proportion of independent directors is $25 \%$, indicating that the proportion of independent directors in some state-owned enterprises has not reached the standard of $1 / 3$.

\subsection{Regression Analysis}

As shown in Table 3, the managerial ownership ratio, equity concentration ratio and equity balance degree, the correlation coefficient between enterprise growth and the return on equity is positive, and the ratio of the asset liability ratio to the independent director is negative. Among them, 
the correlation coefficient of managerial ownership, balance of ownership, asset liability ratio and growth of enterprise and the return on equity is more significant. All variables except the proportion of managerial ownership and asset liability ratio correlation coefficient -0.457 and ownership concentration and equity balance degree of correlation coefficient between the 0.447 , other correlation coefficients are small, so use the regression model to study the effect of managerial ownership on firm performance is meaningful.

Table 3. Correlation analysis.

\begin{tabular}{llllllll}
\hline & & ROE & MTO & OC & SPR & DB \\
\hline ROE & Pearson Correlation & 1 & & & & & \\
MTO & Pearson Correlation & $.238^{* *}$ & 1 & & & & \\
OC & Pearson Correlation & .011 & .024 & 1 & & \\
SPR & Pearson Correlation & $.147^{*}$ & $-.189^{* *}$ & .447 & 1 & \\
DB & Pearson Correlation & $-.267^{*}$ & -.457 & -.027 & .017 & \\
ID & Pearson Correlation &.-051 & .036 & .217 & $.151^{*}$ & .080 \\
EG & Pearson Correlation & $.243^{* *}$ & .074 & -.065 & $-.161^{*}$ & $.157^{*}$ & .024 \\
\hline
\end{tabular}

**. Correlation is significant at the 0.01 level (2-tailed).

Table 4 shows the regression equation:

$\mathrm{ROE}=0.226 \mathrm{MTO}+0.285 \mathrm{OC}+0.039 \mathrm{SPR}-0.098 \mathrm{DB}-0.041 \mathrm{ID}+0.037 \mathrm{EG}+\varepsilon$.

The proportion of managerial ownership, ownership concentration and equity balance degree coefficients are positive, that the rate of return on net assets and the positive correlation between managerial ownership and significant probability proportional coefficient $\mathrm{T}$ test statistic for $0.044<0.05$, shows that the proportion of managerial ownership effect on net assets yield significantly. The coefficient of the proportion of independent directors is negative, that there is a negative correlation between the rate of return on net assets and the proportion of independent directors, and the significant probability coefficient $\mathrm{T}$ test statistic for $0.045<0.05$, obviously, that the independent directors of the state-owned enterprise of China and did not play its due role in governance.

Table 4. Coefficients(Dependent Variable: ROE).

\begin{tabular}{|c|c|c|c|c|c|c|}
\hline \multirow{2}{*}{\multicolumn{2}{|c|}{ Model }} & \multicolumn{2}{|c|}{ Unstd C } & \multirow{2}{*}{$\begin{array}{l}\text { Std C } \\
\text { Beta } \\
\end{array}$} & \multirow{2}{*}{$\mathbf{t}$} & \multirow{2}{*}{ Sig. } \\
\hline & & B & Std. Error & & & \\
\hline \multirow{6}{*}{1} & (Constant) & 3.002 & 10.919 & & .275 & .078 \\
\hline & MTO & .226 & .125 & .433 & 1.807 & .044 \\
\hline & $\mathrm{OC}$ & .285 & .161 & .546 & 1.770 & .351 \\
\hline & SPR & .039 & .181 & .080 & .218 & .059 \\
\hline & DB & -.098 & .104 & -.207 & -.938 & .358 \\
\hline & ID & -.041 & .209 & -.037 & -.198 & .045 \\
\hline
\end{tabular}

From table 5 and table 6 , the correction coefficient is 0.404 , and the fitting effect of the model is ideal. And in the significance test of equation, the $\mathrm{F}$ value is $0.000<0.05$, which is highly significant.

Table 5. Anova.

\begin{tabular}{llllll}
\hline Model & & Sum of Squares & df & Mean Square & F \\
\hline \multirow{3}{*}{1} & Regression & 4971.911 & 6 & 828.652 & 7.112 \\
& Residual & 23069.059 & 198 & 116.510 & \\
& Total & 28040.970 & 204 & & \\
\hline
\end{tabular}

a. Predictors: (Constant), EG, ID, MTO, OC, DB, SPR

b. Dependent Variable: ROE

Table 6. Model summary.

\begin{tabular}{lllll}
\hline Model & R & R Square & Adjusted R Square & Std. Error of the Estimate \\
\hline 1 & $.729^{\text {a }}$ & .532 & .404 & 6.70987 \\
\hline
\end{tabular}

a. Predictors: (Constant), EG, OC, DB, MTO, ID, SPR

\section{Conclusions and Recommendations}

\subsection{Conclusions}

Rate of return on net assets of state-owned enterprises and the proportion of managerial ownership, ownership concentration and equity balance degree of positive correlation, significant probability and management shareholding ratio coefficient $\mathrm{T}$ test statistic for $0.044<0.05$, indicating the proportion of managerial ownership effect on net assets yield significantly. The coefficient of the proportion of independent directors is negative, that there is a 
negative correlation between the rate of return on net assets and the proportion of independent directors, and the significant probability coefficient $\mathrm{T}$ test statistic for $0.045<0.05$, obviously, that the independent directors of the state-owned enterprise of China and did not play its due role in governance.

\subsection{Recommendations}

Mixed ownership reform is an important measure to uphold and improve the basic economic system of China, 1 in the third Plenary Session of the 18th CPC Central Committee after the development of mixed ownership economy on the agenda and points out that in order to study the implementation of the policies and measures of realizing public ownership in various forms, according to the the relaxation of market access, the development of mixed ownership economy reform all requirements, promote enterprises in the restructuring and listing, mergers and acquisitions, project investment, the introduction of private capital and strategic investors actively, comprehensively promote the reform of state-owned enterprises into joint-stock companies. [20] In the above policy, the concept of introducing private capital and strategic investors is put forward. The introduction of investment capital in broad sense includes the introduction of strategic investors, financial investors and management through the holding of capital. While management can effectively solve the shareholding reform of state-owned enterprises of mixed ownership in the absence of the owner; can reduce agency cost, achieve maximum principal interests; to optimize the structure of corporate governance, increasing the value of state-owned enterprises.

The following recommendations are made on the management stock ownership:

First, the courage to explore, dare to trial and error, not will pilot the way mechanically, combined with their own actual situation through managerial ownership and reduce agency cost, solve the principal-agent problem, improve business performance and enhance the vitality of state-owned enterprises and the market competitiveness, achieve breakthroughs in the development of the state-owned enterprises.

Second, the stock system as a breakthrough, the establishment of long-term incentive and restraint mechanism of the core personnel, breaking unnecessary restrictions, let go of the system, and better play the role of entrepreneurs. First of all, the state-owned enterprises in the highly competitive industry, both large and small, should be managed by the management team. Then the state-owned enterprises competitive industry, the state-owned capital to avoid the dominance of state-owned capital, holding a relatively uniform in managerial ownership implementation at the same time, the introduction of private capital should be the proportion of large shareholders, state-owned capital owners lack of practical problems can really solve the. Three

1 Yanbing. Geng ownership again: the reform of state-owned enterprises of mixed economic reports. 21 century, 2013, 11, 14 is for state-owned listed companies should cancel the management incentive equity ownership ratio ceiling (1\%), equity incentive income limit (40\%) limit, listed companies to issue shares to management orientation should be allowed.

Third, the optimization of corporate governance of state-owned enterprises, combining with the particularity of state-owned enterprise governance classification [21], while managerial ownership has a positive effect on the rate of return on net assets, but managerial ownership just one form of mixed ownership does not apply in all cases, the fundamental to efforts to create a scientific division of the management team, the formation of modern corporate reasonable governance structure [6]. Because of the independence of independent directors, diffrerent from internal directors, the higher the proportion of executives, more conducive to stand in an objective perspective in order to truly improve the corporate governance mechanism and supervision mechanism of thinking, at the same time is also more perfect, to reduce the possibility of collusion, in order to achieve the company to maximize the benefits for the goal. Therefore, the independent director system in major decisions on the future development and play an increasingly important role in China, but compared with other developed countries, the independent director system is not perfect, but also is in the early development of reforming the system of the board of directors, the independent director proportion is low, even state-owned listed the company is still not reached.

\section{Acknowledgements}

This paper is a periodical achievement of National Social Science Fund youth programs "Research on the obstacles and Countermeasures of managerial ownership in mixed ownership enterprises" (14CGL016), Project of self financing of science and Technology Department of Hebei provincial science and Technology Department "Research on system path choice of enterprise technological innovation" (164576484).

\section{References}

[1] Weng Weng. "Review of the reform of state-owned enterprises." China economic report, 2015(8): 59-61.

[2] YD Yang. Discussion on the Mixed Ownership Economy Reform Promoted by Large State-owned Enterprises. Copper Engineering, 2014(5).

[3] G Wei. Senior management incentive and operating performance of listed companies [J]. Journal of economic studies, 2009(3): 59-61.

[4] ZQ Li. Incentive Mechanism and Company Performance: An Empirical Study on Listed Company [J], Accounting Research, 2000(1): 24-30.

[5] ZZ Yuan, XF Ju. Stock price informativeness and corporate investment efficiency: Evidence from Chinese manufacturing listed companies between 2001 and 2005. International Conference on Management Science, 2008. 
[6] Z Baicheng, WANG Beixing. A Study on the Relation of Corporate Governance, Performance and Top Management Compensation in China. Application of Statistics \& Management. 2007, 26 (4): 669-675.

[7] Tong Aiqin, Shao Xin, Du Dan, Research on the Relationship between Top Manager Characteristics and Corporate Performance: Based on Comparison between State-owned and Non-State-Owned Listed Companies, Science of Science and Management of S. \&T. 2012(1): 166-172.

[8] Joseph. Stiglitz. Whither Socialism. Economic Journal, 1996, 34(1): 189-191.

[9] Sanders, WM. Gerard. "Strategic Management: A Dynamic Perspective, Concepts and Cases." 2007.

[10] Martin. J. Conyon, Graham. V. "Executive pay, tournaments and corporate performance in UK finns." International Journal of Management Reviews, 2001.

[11] H. Youny Baek and Jouny W. Kim. Equity--Based Executive Compensation Plan and Fim Performance: A Residual Income Approach. Working Paper, 2003.

[12] Mehran H. "Executive Compensation Structure, Ownership and Firm Performance." Journal of Financial Economics, 199538(2): 163-184.

[13] Morck R., A. Shleifer, Vishny. "Management ownership and market valuation: an empirical analysis". Journal of Financial Economics, 1988, 20(1-2): 293-315.

[14] A Musacchio, F Floresmacias. "The return of state-owned enterprises: Should we be afraid?" Harvard Business Review, 2009,4 .

[15] N. Gregory Mankiw. "Principles of Macroconomics." [M]. Worth Publishers, 1997.

[16] Ye Genying. Financial Thinking on the development of mixed ownership economy [J]. China Chief Financial Officer, 2014 (9): 60-61.
[17] Li Yueping. The essence of returning to enterprise: the path choice of state-owned enterprise mixed ownership reform [J]. economic theory and economic management, 2015, V35 (1): 22-25.

[18] Wang Xiaolong, Zhao Qiuju. Understanding and thinking of the reform of mixed ownership [J]. finance and economics, 2016 (5): 17-18.

[19] Shao xijuan. Analysis of the Du Pond system [J]. Friends of Accounting, 2006(12): 3 .

[20] Yuan Shaohua. On improving the corporate governance structure of state-owned enterprises [J]. Modern SOE Research, 2016(16).

[21] Li Weian. Classified Governance: the foundation of deepening reform of state-owned enterprises [J]. Nankai business review, 2014, 17 (5): 1-1.

[22] [PL]W. Brus, K. Laski. From Marx to market [M]. Translated by Yin Wenquan et. Shanghai people's publishing house, 1998.

\section{Biography}

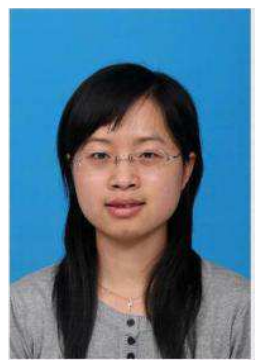

Gao Li, female, Han, born in 1981 in Yangquan, Shanxi, associate professor of Tianjin Foreign Studies University International Business School, master instructor, teacher of Department of accounting. $\mathrm{Ph}$. D. in corporate governance research center, Nankai University. Research interests: corporate governance, investor relations management, corporate finance. 